\title{
Determinates of Capital Structure in Case of Private Commercial Banks in Ethiopia
}

\author{
Tamiru Anley Alebachew \\ Department of Accounting and Finance, Mekdela Amba University, Mekane Selam, Ethiopia \\ Email address: \\ tamiruanley7@gmail.com \\ To cite this article: \\ Tamiru Anley Alebachew. Determinates of Capital Structure in Case of Private Commercial Banks in Ethiopia. Journal of Finance and \\ Accounting. Vol. 8, No. 5, 2020, pp. 221-229. doi: 10.11648/j.jfa.20200805.13
}

Received: August 10, 2020; Accepted: August 24, 2020; Published: September 24, 2020

\begin{abstract}
This study was conducted on the title determinants of capital structure; evidence from private commercial banks in Ethiopia. To find out what determines capital structure, seven bank specific explanatory variables (Profitability, tangibility, growth, age, tax shield, size and liquidity) was selected and regressed beside the suitable capital structure measure (Debt to Equity Ratio). Fourteen private commercial banks, which had minimum of seven years life were selected for the study. Their audited financial statement from 2013 to 2019 was used as major source of data. Before the analysis of regression model test of CLRM assumptions such as normality, multicollinearity, heteroscedastcity and autocorrelation tests were conducted on the data. After these tests, Hauseman model specification test conducted and its result indicated that Fixed Effect Model was better to test hypotheses that emerge through the review of existing literature. Then inferential statistics regression was done by Fixed Effect Model (FEM). The regression result reveled that profitability, age, tax shield and size had significant effect on leverage. However, among the hypothesized capital structure determinants growth, asset tangibility and liquidity had insignificant effect on capital structure of Ethiopian private commercial bank. In addition, trade-off theory and the pecking order theory explained the capital structure behavior of banking industry in Ethiopia.
\end{abstract}

Keywords: Capital Structure (Leverage), FEM, Trade-off Theory, Packing Order Theory, Private Commercial Bank

\section{Introduction}

Capital structure is a method in which a firm's assets are financed. It is a combination of different types of equity and debt capital that firms kept resulting from its' financing decisions [27]. Sound capital structure of a company, helps to rises firms value, utilization of available funds, minimization of cost of capital and to manage solvency or liquidity position. In addition, it enables banks to acts as a buffer to absorb losses incurred in times of financial stress. Therefor sound capital structure in bank provides security and safeguard to depositors and lender [9]. Bank quiet has to rely on high level of debt to finance its ongoing and main business of lending.

Banks has distinctive characteristic as compared to other firms. Banks need to follow certain rules and regulations as a hedge against instabilities in their financial positions. Specifically, minimum capital requirement is obligatory on banks as to how they should handle their assets in relation to their capital mix. But, banks hold more capital than the minimum capital ratios required by capital regulations that banks are obliged to meet [20]. This is due to that banks tend to operate in a prudential manner against probable shocks like 2008 crisis in banks [28].

\subsection{Research Problem}

For one country economic development commercial banks has decisive role. Especially a healthy banking industry has undisputable impact on the mobilization financial resource [11]. To obtain this major benefit of bank identifying the determinants of commercial banks capital structure is very important, because capital structure is one of the determinants of banks profitability [15]. And the other reason is banks leverage and banks crisis had positive relationship [1]. This study has importance for developing country like Ethiopia to accelerate the growth of financial sectors.

Different indicates that financial decisions in developing 
countries are somehow different from those of developed ones, because of their institutional differences such as investor protection and level of transparency, besides the bankruptcy and tax laws [37, 20]. In addition factors affecting capital structure vary from one country to the other due to differences in the level of social, environmental, economic, technological and cultural development [25]. Especially in Ethiopia varies from some other developing countries, because there is no secondary capital market in Ethiopia which makes things easier to raise funds and choose the best mix of debt and equity sources. Consequently, research discoveries from one country cannot be generalized to other countries. So that, it is interesting to see, what are the exact determinants of capital structure in an industry of a specific country?

Most of the time national or central bank regulation on reserve amount considered as the only determinate for banks leverage. However, it is not the only determinate rather is serve as initial point to discussion and to find more other factors? Therefore, this paper will fills the above stated gaps and problems by identifying the factor that determine capital structure decision and providing additional facts to the theories of capital structure by evidencing private commercial banks in Ethiopia.

\subsection{Research Objective}

The general objective of the study was to examine determinants of capital structure in case of privet commercial banks in Ethiopian. Specific objectives this study will try to achieve the following objectives:

1) To examine the effect of profitability on capital structure

2) To examine the effect of tangibility on capital structure

3) To examine the effect of growth on capital structure

4) To examine the effect of age on capital structure

5) To examine the effect of tax-shield on capital structure

6) To examine the effect of size on capital structure

7) To examine the effect of liquidity on capital structure

8) To identify which theory explains the financing behavior of Ethiopian banking industry.

\subsection{Research Hypothesis}

1) Ha1: There is a significant positive relationship between liquidity and leverage.

2) Ha2: There is a significant positive relationship between tangibility and leverage.

3) Ha3: There is a significant positive relationship between profitability and leverage

4) Ha4: There is a significant positive relationship between size and leverage

5) Ha5: There is a significant positive relationship between age and leverage

6) Ha6: There is a significant positive relation between growth opportunities and leverage.

7) Ha7: There is a significant positive relation between tax-shield and leverage.

\section{Review of Related Literature}

\subsection{Meaning of Capital Structure}

In their job financial manager make decision on three great areas which determine the fate of their company or firm. These financial manager decision areas are: investment decision, financing decision (capital structure) and dividend decision

Capital structure is the second important decision which finances manager has to make. Financing decision concern is to answer the question, how much to rise from which source financing? The financial manager should watch over the capital structure of the company, determining the best mix of debt and equity is too important [40].

Capital structure is the mixture (proportion) of a firm's permanent long-term financing denoted by debt, preferred stock, and common stock equity [41]. Again it is the mix of debt, preferred stock, and common equity with which the firm plans to raise capital [7]. Optimal Capital Structure is the capital structure that maximizes a firm's stock price. Target Capital Structure is the mix of debt, preferred stock, and common equity the firm wants to have. Optimal capital structure is one in which the marginal real cost of each available method of financing is the same. In general capital structure is how a firm finances its overall operations and growth by using different sources of funds [40].

\subsection{Theory of Capital Structure}

To remember the first capital structure theory we have to go back to 1958 Miller and Modigliani. These two economists develop the first capital structure theory called irrelevancy or MM theory. They state that the value of a firm is independent from its corporate financing decisions under certain assumptions, but market environment does not exist in the real world as per their assumption. However, their theory serves as standing point for other researcher and scholar. Following MM theory like Mayer's Donaldson and others are inspired to develop further theories and researches

\subsubsection{Trade off Theory}

Trade-off theory originated after the debate of ModiglianiMiller theorem. Trade off theory came on the opposite side of irrelevance theory. This theory proposed on the benefit of corporate income tax. In corporate income tax interest expense is deducted before tax and this deduction help firm specially banks to reduce taxable income. This minimum taxable income helps firms to make smaller the amount of tax to be paid [9]. A firm that follows the trade-off theory sets a target debt-to-value ratio and then step by step go towards the target. The target is determined by balancing debt tax shields against costs of bankruptcy [30]. Optimal capital structure is developed by firms by trading off the costs of debt and equity against their benefits. As said in the above the major motive for firms to use debt is the pro of debt tax shield. On the other side cost of potential financial distress may be the demerits of debt, predominantly when a firm acquires too 
much debt. In general, for this theory origination tax deductibility of interest expense is the main reason and this promotes the application of debt $[21$.

\subsubsection{Packing Order Theory}

The Pecking Order Theory originated by Donaldson's in 1961 and he states that firms prefer to use internally generated funds as a financing source and then alternative to externals funds only if the need for funds was mandatory [13]. In packing order theory firms have a preference on internal finance than external finance (Information asymmetries are assumed relevant only for external financing) [30, 32]. If external financing is compulsory, firm can issue either debt or equity to finance new investment. Mostly firms will issue the safest security first, that is, debt before equity. Issuing debt minimizes the information advantage of the corporate managers [31]. External funds can be very costly due to floatation costs and the problem of asymmetric information, especially for financially constrained firms [12].

\subsubsection{Agency Costs Theory}

Agency cost theory was developed by Jensen and Meckling in their 1976 publications. This theory reflect debt to be an essential factor that creates conflict among equity holders and managers. Agency costs are a type of internal cost that arises from and/or must be paid to an agent acting on behalf of a principal. These costs happen because of core problems. Conflict of interest between shareholders and management is the major problem [22]. For instance the managers may hence put less efforts in value enhancement activities and may also carry out to increase their private gains by extravagant perquisites, luxurious bureaus, through sub-optimal investments, etc. [23].

\subsubsection{Market Timing Theory}

Market timing theory claims that when companies make decision of capital structure, the timing of the market is more important than firm specific determinants [3]. They primarily base their decision on how the financial markets value debt and equity respectively and make their decision based on that. For example, when the market value of their company is high, managers would be more motivated to issue equity. When their market values have dropped however, they would be more inclined to repurchase their equity. In general in this theory there is no optimum capital structure rather in market timing financing decision just accumulates over time into the capital structure outcome.

\subsubsection{Signaling Theory}

Signal is an action taken by a firm's management that gives some indications to investors about how management views the firm's prospects. Signaling theory was develop by Ross in 1977. MM assumed that everyone investors and managers equally has the same information about a firm's prospects. This is called symmetric information. However, managers often have superior information than outside investors. This is leads to the presence of asymmetric information, and it has significant effect on the optimal capital structure. For instance firms with extremely bright prospects prefer not to finance through new stock offerings, whereas firms with poor prospects like to finance with outside equity. Therefore, rational investors should lower their estimate of the firm's value, other things held constant, if firms plan to issue new stock [7].

\subsection{Empirical Literature Review}

According to [19] finding indicates that leverage has positive relationship with fixed assets, non-debt tax shields firm size and investment opportunities, but in contrast it has negative correlation with advertising expenditure, volatility, the probability of bankruptcy, uniqueness of the product and profitability. A study on the determinants of capital structure choice evidence from Polish companies. Capital structure has inverse relation with assets structure, dividend policy and firm size. The evidence generally suggests the relevance of the pecking order hypothesis in explaining the financing choices of Polish firms [25].

The determinants of the capital structure of banks in European Union. It's find inflation, tangibility, size of a bank, profitability, the ratio liquid assets to Deposits and short term funding had significant effect on leverage ( net loan over total asset) [35].

A study conducted on determinants of banks leverage and its findings show that profitability, size, tangibility and liquidity of the banks are important determinants of capital structure of banks in Ethiopia. However, growth and risk of banks are found to have no statistically significant impact on the capital structure [42].

\section{Research Methodology}

Research designs are plans and the procedures for research that span the decisions from broad assumptions to detailed methods of data collection and analysis [10]. This study had explanatory research design. Explanatory research is defined as an attempt to connect ideas to understand cause and effect relation of variables. This indicates that this study focused on identifying the relationship of explanatory variables and the dependent variable. In addition, this research followed quantitative research approach.

\subsection{Population and Sample}

To examine determinants of capital structure data was collected from private commercial banks in Ethiopia. According to National Bank of Ethiopia report currently in Ethiopia there are seventeen commercial banks. From these banks Commercial Bank of Ethiopia did not included because it is held by government. In Ethiopia there are 16 private commercial banks [33]. From these banks only 14 banks which had 7 years life and above were selected as a sample.

\subsection{Data Type, Source and Collection}

Panel data was employed to determine or estimate the relationship of dependent and independent variable. Panel data consist of observations on the same cross-sectional, or individual, units over several time periods. There are several 
advantages to using panel data. First, they increase the sample size significantly. Second, by studying repeated cross-section observations, panel data are better suited to study the dynamics of change. Third, panel data enable us to study more complicated behavioral models [18]. This study data was collected from each bank audited financial statement from 2013 up to 2019.

\subsection{Variable Description}

Seven bank specific factors were tested and these seven bank specific factors are i.e. profitability, tangibility, growth, age, tax-shield, size and liquidity. Leverage is a dependent variable of the study.

$$
\begin{aligned}
& \text { (LEV)leverage or Debt to equity Ratio }=\frac{\text { Total Debt }}{\text { Total Share Holders' Equity }} \\
& \text { (PR)Profitability }=\frac{\text { Net Income }}{\text { Total Assets }} \\
& (\mathrm{TN}) \text { Tangibility }=\frac{\text { Fixed Assets }}{\text { Total Assets }} \\
& \mathrm{Yi}, \mathrm{t}=\beta 1 \mathrm{Xi}, \mathrm{t}+\alpha \mathrm{i}+\text { ui.t }
\end{aligned}
$$

\subsection{Model Specification} (REM) based on Hausman's specification test result $[16,18]$. better for ths study. effects model becomes:

$$
\mathrm{LEV}=\beta_{0}+\beta_{1}(\mathrm{PR}) \mathrm{i}, \mathrm{t}+\beta_{2}(\mathrm{TN}) \mathrm{i}, \mathrm{t}+\beta_{3}(\mathrm{AG}) \mathrm{i}, \mathrm{t}+\beta_{4}(\mathrm{GR}) \mathrm{i}, \mathrm{t}+\beta_{5}(\mathrm{SZ}) \mathrm{i}, \mathrm{t}+\beta_{6}(\mathrm{TXS}) \mathrm{i}, \mathrm{t}+\beta_{7}(\mathrm{LQ}) \mathrm{i}, \mathrm{t}+\mu \mathrm{i}, \mathrm{t}
$$

\section{Data Analysis}

\subsection{Pre Estimation Test}

\subsubsection{Normality Test}

Normality test is conducted to decide whether a data is wellmodeled by a normal distribution or not. To check whether the data normal or not, it is possible to use histogram, skewness / kurtosis test, Shapiro-Wilk W test... etc. Normality test Shapiro Wilk W test was used conducted. Theoretically in this test, if P value above 0.05 shows the test result is insignificant, then the data are normal and null hypothesis normal distribution is accept. On the opposite side, if $P$ is less than 0.05 , then the data is not normal and so null hypothesis is rejected.

Table 1. Shapiro-Wilk W Test for Normality.

\begin{tabular}{llllll}
\hline \multicolumn{2}{l}{ Shapiro-Wilk W Test } & & & & \\
\hline Variable & Obs & W & V & Z & Prob $>$ Z \\
\hline Residual & 98 & 0.99326 & 0.657 & -0.941 & 0.82667 \\
\hline
\end{tabular}

As table 1 results indicates Shapro- Wilk W test revealed that $\mathrm{p}$-value 0.8267 is above 0.05 . Therefore, the data are normal or normally distributed.

\subsubsection{Tests for Heteroskedasticity}

Table 2. Breusch-Pagan/Cook-Weisberg test for Heteroskedasticity.

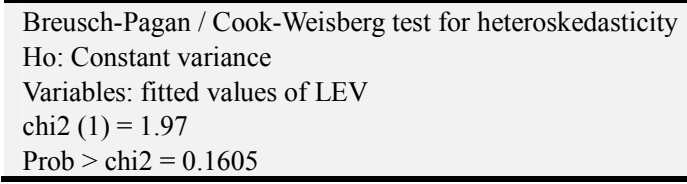

In table 2 result of Breusch and Pagan lagrangian multiplier test for heteroskedasticity shows that prob $>$ chi2 equal to 0.1605 which is above $\mathrm{P}$ value 0.05 . This indicates that there was no heteroskedasticity problem. So that null hypothesis i.e. residual has constant variance accepted. 


\subsubsection{Tests for Multicollinearity}

Multicollinearity refers to the presence of linear relationship between some or all explanatory variables of a regression model [18]. The VIF result in Table 3 indicates that none of the VIFs excessively higher than 10 and this proposes the absence of perfect or strong collinearity between the explanatory variables. As concluding almost all variables have low correlation power and this implies that there was no significant multicollinearity problem in the selected explanatory variables.

Table 3. VIF test.

\begin{tabular}{lll}
\hline Variable & VIF & 1/VIF \\
\hline SZ & 6.64 & 0.150539 \\
AG & 3.85 & 0.259929 \\
TXS & 3.03 & 0.330503 \\
GR & 1.94 & 0.515906 \\
LQ & 1.45 & 0.688204 \\
TN & 1.41 & 0.707396 \\
PR & 1.23 & 0.815422 \\
Mean VIF & 2.44 & \\
\hline
\end{tabular}

\subsubsection{Autocorrelation Test}

This study Durbin-Watson test result was 1.4749. Since 1.474 was found between 1.1357 and 1.741 , so we could not reject the null hypothesis no autocorrelation. So that autocorrelation did not significantly affect our model.

\subsubsection{Ramsey RESET Test for Omitted Variables}

Ramsey RESET test using powers of the fitted values of LEV

Ho: model has no omitted variables

$\mathrm{F}(3,109)=0.65$

Prob $>\mathrm{F}=0.5873$

RESET test result fails to reject the null hypothesis of no omitted variables indicating no model specification error.
This test result did not mean that all explanatory variables included in the study, rather it indicates that our model embraced most of the variable necessary to explain dependent variable leverage.

\subsubsection{Hausman Specification Test}

To prefer the best model from fixed effect model and random effect model hausman specification test conducted. As table 4 indicates Hausman specification test result shows that fixed effects model bitterly fit than random effects model for this study, because p-value is equal to 0.00 and this is less than 0.05 for dependent variables i.e. leverage. So that the null hypothesis of random effect model was rejected, and reached to a conclusion that the fixed effect estimate was preferable.

Table 4. Hausman Specification Test.

\begin{tabular}{|c|c|c|c|c|}
\hline \multicolumn{5}{|c|}{ Correlated Random Effects - Hausman Test } \\
\hline \multicolumn{5}{|c|}{ Test cross-section random effects } \\
\hline \multicolumn{2}{|c|}{ Test Summary } & Chi-Sq. Statistic & Chi-Sq. d. f. & Prob. \\
\hline \multicolumn{2}{|c|}{ Cross-section random } & 58.646758 & 7 & 0.0000 \\
\hline \multicolumn{5}{|c|}{ Cross-section random effects test comparisons: } \\
\hline Variable & Fixed & Random & Var (Diff.) & Prob. \\
\hline PR & -42.015513 & -36.164098 & 15.777155 & 0.1407 \\
\hline LQ & 1.172587 & 2.013889 & 0.046119 & 0.0001 \\
\hline AG & -0.821998 & -0.231836 & 0.007687 & 0.0000 \\
\hline SZ & 3.154586 & 1.804725 & 0.060197 & 0.0000 \\
\hline GR & 0.391454 & -0.307304 & 0.032923 & 0.0001 \\
\hline TXS & 0.312101 & 0.361251 & 0.000692 & 0.0617 \\
\hline $\mathrm{TN}$ & -21.865205 & -49.904522 & 36.054389 & 0.0000 \\
\hline
\end{tabular}

\subsection{Fixed Effect Models Regression Result}

Based on the above hausman model selection test result fixed effect model was selected. Due to this the regression was conducted based on fixed effect model.

Table 5. Fixed Effect Model Regression.

\begin{tabular}{|c|c|c|c|c|}
\hline \multicolumn{5}{|c|}{ Dependent Variable: LEV } \\
\hline \multicolumn{5}{|c|}{ Method: Panel Least Squares } \\
\hline \multicolumn{5}{|l|}{ Sample: 20132019} \\
\hline \multicolumn{5}{|l|}{ Periods included: 7} \\
\hline \multicolumn{5}{|c|}{ Cross-sections included: 14} \\
\hline \multicolumn{5}{|c|}{ Total panel (balanced) observations: 98} \\
\hline Variable & Coefficient & Std. Error & t-Statistic & Prob. \\
\hline $\mathrm{C}$ & -59.10435 & 7.364390 & -8.025696 & 0.0000 \\
\hline PR & -42.01551 & 13.61753 & -3.085399 & $* 0.0026$ \\
\hline LQ & 1.172587 & 0.768113 & 1.526581 & 0.1301 \\
\hline AG & -0.821998 & 0.105379 & -7.800380 & $* 0.0000$ \\
\hline SZ & 3.154586 & 0.381893 & 8.260384 & $* 0.0000$ \\
\hline GR & 0.391454 & 1.149465 & 0.340553 & 0.7342 \\
\hline TXS & 0.312101 & 0.127580 & 2.446313 & $* * 0.0162$ \\
\hline $\mathrm{TN}$ & -21.86520 & 15.62435 & -1.399431 & 0.1649 \\
\hline & Effects Specification & & & \\
\hline \multicolumn{5}{|c|}{ Cross-section fixed (dummy variables) } \\
\hline R-squared & 0.868782 & Durbin-Watson stat & & 1.474946 \\
\hline Adjusted R-squared & 0.836316 & & & \\
\hline F-statistic & 26.75947 & * refers significant at & & 1 percent \\
\hline Prob (F-statistic) & 0.000000 & ** refers significant at & & 5 percent \\
\hline
\end{tabular}

The above table 5 shows that adjusted $\mathrm{R}$ square was 83

percent which indicates that about 83 percent of change in 
leverage was explained by the selected factors (Profitability, liquidity, age, size, growth, tax shield and Tangibility). This indicates that majority of the variations in the capital structure of understudied bank in Ethiopia highly influenced by the independent variables selected for this study.

Fixed effect regression result shows that profitability had negative relation with leverage ratio at one percent significant level ( $p$-value $=0.0026$ ). Similarly age had negative relation at one percent statistically significant level ( $\mathrm{p}$-value $=0.00)$. On the contrary, size had strong positive relationship with leverage ratio at one percent statistical significance level. In the same way, tax shield was statistically significant $(\mathrm{p}$-value $=0.0162$ ) at five percent significance level and had positive relation with leverage ratio. In addition liquidity and growth had positive but insignificant relation with leverage ratio. However, tangibility had negative relationship with debt to equity ratio but it is insignificance. To sum up, from all explanatory variables four had significant effect and the rest had insignificant effect on debt to equity ratio or leverage of banks.

Bank size. The result of beta coefficient linked with bank size is consistent with null hypothesis and proved the existence of strong positive relationship between leverage and size. This relationship is found to be statistically significant at 1 percent significance level with the coefficient 3.155 and $\mathrm{p}$ value is 0.00 . This proposes that larger commercial banks in Ethiopia tend to have higher leverage ratios and borrow more capital than smaller commercial banks do. As the size of the bank increase the use of debt financing rise at the same time. The observed result was consistent with the proposition of static trade-off theory and agency cost theory. Major previous empirical studies also found a positive relationship between size and leverage. For instance: $[19,39,36,6,16]$ and [18] revealed in their study the existence of significant and direct relationship between size and leverage. Since the result of size indicated a significant statistics, it is estimated that size has significant role on the capital structure of private commercial banks in Ethiopia. Typically big banks are preferable by customers specially depositor, because large banks are expected to have lower bankruptcy costs. Due to this big bank can simply attract deposits from individuals and corporations and this capacity leads these banks to have tendency to rely more on debts as very cheap source of financing.

Age. The relationship of age with leverage was found to be negative and statistically significant at one percent significance level. This result indicates inconsistency of our prediction with regression result. In addition this statistical result is inconsistence with trade off theory. In the opposite side this negative beta coefficient of variable age was consistent with packing order theory. This study finding on variable age had similar relation with some previous studies like [34]. This result in turn indicates that older banks bit by bit built tough capital and this make them not only rely on debt financing. In general as banks age increases the amount of leverage or debt to equity ratio decline gradually and makes them not only depend on customer's deposit. In addition, this gradually constructed capital helps them not to affect easily by financial shock like other younger banks face. Higher capital reduces the chance of banking crises [4].

Tax shield had a coefficient 0.312 with p-value 0.01 which is significant at five percent significance level. This positive relationship rises because in the banking industry holding of high debt in the total asset increases tax shield amount. To exploit this benefit banks use more debt and this action leads the relationship between tax-shield and leverage became positive. This result of the regression had consistence with tradeoff theory for short term loan but contradicts with long term loan. In Ethiopia and other developing countries banks mostly use short term finance.

The existence of positive relationship between leverage and tax-shield is not that much surprising, because one of the major function of bank is to accept deposits and provide loan. Due to this large amount of their expense is covered by interest expense. These interest expenses are deductible before tax which reduces the amount of tax they are going to pay. To use this advantage banks always want to raise their tax-shield by increasing their deposit or liability. This action on the other side leads them to have high liability in their balance sheet. Therefore, tax shield had positive significant influence on leverage ratio or capital structure of commercial banks sector in Ethiopia. Some of previously studies result support this finding for instance [24].

Profitability. The correlation, between profitability and leverage ratio, is negative significant at one percent significance level. This correlation is in line with hypothesis three. In addition the result of this study is consistent with the pecking order theory that suggests profitable firms prefer internal financing than external financing. This result is inconsistent with predictions of static trade of theory and agency cost theory rather it is consistent with packing order theory. This result revealed the suggestions that profitable banks accumulate internal reserves and this enables them to depend less on external funds. Even though, profitable banks may have better access to external financing, the need for debt finance may possibly be lower, if new investments can be financed from accumulated reserves. Beside, an inverse correlation between profitability and leverage was witnessed in the majority of empirical studies $[6,5,39,18,36,19]$ and [20] they evidenced the existence of negative relationship of profit and leverage. In general, profitability had strong negative effect on debt to equity or leverage of private commercial banks in Ethiopia.

\subsection{Consistency of Observed Result with Different Theories Predicted Sign}

Following Modigliani and Miller finding of 1958 many researches has been conducted to identify determinants of leverage and also different scholars develop different theories. However, prior empirical study's findings provided different evidence concerning to the impact of factors on capital structure and there is no one theory that is universally acceptable by all. Furthermore, the majority of these studies 
have been conducted in developed countries.

Table 6. Observed Sign and Theoretical Prediction of Explanatory Variable.

\begin{tabular}{lllllll}
\hline Variables & Trade off theory sign & $\begin{array}{l}\text { Packing order theory } \\
\text { sign }\end{array}$ & $\begin{array}{l}\text { Agency cost } \\
\text { theory sign }\end{array}$ & Expected sign & Actual result sign & $\begin{array}{l}\text { Hypothesis test } \\
\text { result }\end{array}$ \\
\hline Tangibility & + & - & + & + & - & rejected \\
Liquidity & + & - & $?$ & + & + & rejected \\
Size & + & - & + & + & + & accepted \\
Age & + & - & $?$ & + & - & rejected \\
Growth & - & + & - & + & + & rejected \\
Tax shield & + & $?$ & $?$ & - & + & accepted \\
Profitability & + & - & ? & - & accepted \\
\hline
\end{tabular}

The theoretical signs of explanatory variables are presented based on the previous capital structure theories and were used by different researchers $[19,39,36,30,16,32$, $22]$, and [24].

+ refers positive relationship with leverage? Refers to no clear prediction

- refers negative relationship with leverage

From the above table 6 we can understand that it is difficult to answer the question, which theory explain clearly the capital structure behavior of private commercial banks in Ethiopia? This happened due to that actual observed result has the behavior of both theories which means some factors support for packing order theory and some other support trade off theory. Profitability, size, age and tax shield play a significant role in explaining the capital structure. Two of these determinants size and tax shield, support the static trade-off theory. Whereas profitability and age supports the pecking order theory. In general Ethiopia commercial banking industry financing behavior had mixed feature of the two major or big capital structure theories i.e. trade off theory and packing order theory.

\section{Conclusion}

This study examined determinants of capital structure of private commercial Banks in Ethiopia. From the total of 16 private commercial banks 14 used as sample for this study and their data analyzed by using fixed effect model. Seven explanatory variables are used in the study. From these variables size, tax shield, age and profitability significantly affect leverage. The remaining three factors i.e. growth, liquidity and tangibility had not significant impact on banks leverage.

1) Profitability had statistically significant negative relationship with leverage, which was in line with our prediction. This result supports the pecking order theory and prefers using internal source finance before looking external source.

2) In the same way bank size had statistically significant and positive relationship with leverage, which was consistent with trade-off theory and the expected sign. The results also suggested that the bigger the bank, the more external funds it will use. The possible reason is that, bigger banks have lower variance of earnings. According to trade off theory large banks has less probability of bankruptcy $[15,29]$.

3) Similarly, age had a negative and statistically significant relationship with leverage, which was not in line with the expected sign. This result also supports the pecking order theory and prefers using internal finance before raising debt or equity. According to packing order theory negative sign suggests that as banks mature, it builds its reputation. This reputation or good name of bank built up over the years and it help them too easily raise internal or equity finance.

4) Another major finding was tax shield effects on leverage. Based on the results of regression analysis; the variable tax shield was the most important factor, which had statistically significant positive effect on leverage. This finding was in line with expected sign and consistent with trade-off theory. This result also supports that interest paid is a deductible expense and it makes debt less expensive than common or preferred stock [7]. Therefore, by taking more debt (deposit) in their capital structure, banks benefit from the interest tax shield. Trade off theory follower argues that high amount of debt in the total asset create high interest payment and this reduce tax mount that going to be payable. This minimum tax amount is arises due to the payment of interest expenses from operating income.

5) In addition, to some extent trade-off theory and the pecking order theory explained the capital structure behavior of banking industry in Ethiopia.

\section{Suggestion}

Future researchers can look the effect of these and other different factors on capital structure in comparison with other developing countries financial institution. Specially conducting this comparison with developing countries which have secondary market is very important. It helps to understand the effect of secondary market absence in capital structure of banks and other firms. In addition applying dynamic panel data regression in future research may make it possible to reveal interesting relationships between short- and long-term leverage.

\section{Conflict-of-Interest Disclosure Statement}

Tamiru Anley

I have nothing to disclose 


\section{References}

[1] Anafo, S. A., Amponteng, E., \& Yin, L. (2015). The impact of capital structure on profitability of banks listed on the Ghana stock exchange. Research Journal of Finance and Accounting, 6 (16), 27-34.

[2] Aregawi, G. (2010, May). Determinants of Capital Structure: Evidence from Commercial Banks in Ethiopia”.

[3] Baker, M., \& Wurgler, J. (2002). Market timing and capital structure. The Jourinal of Finance, LVII (1), 1-32.

[4] Baker, M., \& wurgler, J. (2013). Do strict capital requirements raise the cost of capital? Banking regulation and the low risk anomaly. NBER Working Paper (19018).

[5] Bauer, P. (2004). Determinants of Capital Structure: Empirical Evidence from the Czech Republic. Journal of Economics and Finance, 1-21.

[6] Booth, L., Aivazian, v., Demirguc-Kunt, A., \& Maksimovic, V. (2001). Capital structure in developing countries. The Journal of Finance, 56 (1), 87-130.

[7] Brigham, E. F., \& Houston, J. F. (2009). Fundamentals of Financial Management. Canada: South-Western Cengage Learning.

[8] Brigham, E., \& Daves, P. (2007). Intermediate Financial Management (9th ed.). Natorp Boulevard Mason, USA: Thomson Higher Education.

[9] Bruce, P. T., \& Pradip, T. (2008). The Impact of Capital Structure on Economic Capital and Risk Adjusted Performance. ASTIN Bulletin, 341-380.

[10] Creswell, J. (2009). Research Design: Qualitative, Quantitative and Mixed Methods Approaches (3rd ed.). California: Sage Publications.

[11] De Jonghe, O. (2010). "Back to the basics of banking? A micro analysis of banking system stability. Journal of Financial Intermediation, 387-417.

[12] Fazzari, S. M., \& Petersen, B. C. (1993). Working Capital and Fixed Investment: New Evidence on Financing Constraints. The RAND Journal of Economics, 24, 328-342.

[13] Donaldson, G. (1961). Corporate Debt Capacity: A Study of Corporate Debt Policy andthe Determination of Corporate Debt Capacity. Division of Research, GraduateSchool of Business Administration, Harvard University, Boston. Economics. 113: 387-432.

[14] George, G., \& Mary, R. (2014). Capital Structure of Kenyan Firms: What determines it? Research Journal of Finance and Accounting, 118-124.

[15] Giday, G. G. (2016). The impact of capital structure on profitability of Commercial Bank of Ethiopia. Journal of Poverty, Investment and Development, 28, 17-36.

[16] Greene, W. H. (2008). ECONOMETRIC ANALYSIS (6th ed.). Upper Saddle River, New Jersey: Pearson Education, Inc.

[17] Grigore, M. Z., \& Stefan-Duicui, V. M. (2013). Agency theory and optimal capital structure. Challenges of the Knowledge Society. Economics, 863-868.

[18] Gujarati, D. N. (2004). Basic Econometrics (4th ed.). West Point: The McGraw-Hill Companies.

[19] Harris, M., \& Raviv, A. (1991). The theory of capital structure. TheJournal of Finance, 16 (1), 297-355.

[20] Hoa, N., \& Zainab, K. (2013). Determinants of banks' capital structure in Asia A comparison amongst developed and developing countries.

[21] Jahanzeb, A., Rehman, S.-U., Bajuri, N. H., Karam, M., \& Ahmadimousaabad, A. (2013). Trade-Off Theory, Pecking Order Theory and Market Timing Theory: A Comprehensive Review of Capital Structure Theories. International Journal of Management and Commerce Innovations (IJMCI), 01 (01), 11.

[22] Jensen, M. C., \& Meckling, W. H. (1976). Theory of the firm: managerial behavior, Agency costs and ownership structure. Journal of Financial Economies, 305-360.

[23] Jensen, M. C. (1986) Agency Costs of Free Cash Flow, Corporate Finance, and Takeovers. The American Economic Review, 76, 323-329.

[24] Kibrom, F. M. (2010, May). Determinants of Capital Structure: Evidence from Commercial Banks in Ethiopia.

[25] Mazur, K. (2007, September 2). The Determinants of Capital Structure Choice: Evidence from Polish Companies. International Advances in Economic Research, 13 (4), 495514.

[26] Malcolm Baker and Jeffrey Wurgler (2013). Handbook of the Economics of Finance, 2, 357-424.

[27] Mohammed, G. (2016). Capital Structure and Financial Performance of Insurance Industries in Ethiopia. Global Journal of Management and Business Research, 16 (7), 4553.

[28] Mooij, R. d., Keen, M., \& Orihara, M. (2013). Taxation, Bank Leverage, and Financial Crises. Internationa Monetary Fund, Working Paper, 1-25.

[29] Muhammed, A., Ashenafi, B., \& Netsanet, S. (2015, December). Does capital structure on performance of banks? (A study in commercial banks in Ethiopia). International Journal of Scientific and Research Publications, 5 (12), 643654 .

[30] Myers, S. C. (1984). The capital structure puzzle. The Journal of Finance, 39 (3), 575-592.

[31] Myers, S. C. (2001, January). Capital Structure. The Jounal of Economic Perspective, 15 (2), 81-102.

[32] Myers, S. C., \& Majluf, N. S. (1984). Corporate financing and investment decisions when firms have information the investors do not have. Journal of Financial Economics, 187221.

[33] National Bank of Ethiopia. (2019). Annual report, Adiss Abebe. Ethiopia.

[34] Ogbulu, O. M., \& Emeni, F. K. (2012). Determinants of corporate capital structure in Nigeria. International Journal of Economics and Management Sciences, 1 (10), 81-96.

[35] Papagianni, E. E. (2013, December). Determinants of the capital structure of banks in European Union. 
[36] Rajan, R., \& Zingales, L. (1995, December). What Do We Know about Capital Structure? Some Evidence from International Data. The Journal of Finance, 50 (5), 1421-1460.

[37] Sasho, A., \& Aleksandar, N. (2016). Determinants of capital structure: An empirical study of companies from selected post-transition economies. Preliminary communication, 34, 119-146.

[38] Reyna, O. T. (2007). Panel Data Analysis Fixed and Random Effects using Stata. Princeton Universty.

[39] Titman, S., \& Wessels, R. (1988, March). Determinats of capital structure choice. The Journal of Finance, 43 (1), 1-19.
[40] Van Horne, J. C. (1971). Financial Management and Policy (2nd ed.). United States of America: PRENTICE-HALL, INC., ENGLEWOOD.

[41] Van Horne, J. C., \& Wachowicz, J. M. (2008). Fundamentals of Financial Management (13th ed.). Harlow England: Pearson Education.

[42] Weldemikael, S. (2012, June). Determinants of Capital Structure of Commercial Banks in Ethiopia. 